\title{
Sistem Informasi Klinik GKI Raya Hankam Berbasis Desktop
}

\author{
Albertus Dimas Pratomo. M'), Ridha Sefina Samosir' ${ }^{2)}$,Erwin Syah Rani ${ }^{\text {3) }}$ \\ Sistem Informasi, Institut Teknologi dan Bisnis kalbis \\ Jalan Pulo Mas Selatan Kav. 22, Jakarta 13210 \\ 1)Email: albertusdimas.dimas@gmail.com \\ ${ }^{2)}$ Email:defa.dmk@gmail.com \\ ${ }^{3)}$ Email: erwin.srany@yahoo.com
}

\begin{abstract}
GKI Raya Hankam Clinic is a health service facility owned by Indonesian Christian Church. GKI Raya Hankam Clinic aims to serve health for the general public who have health problems. The purpose of this research is to build and implement a clinical information system GKI Raya Hankam based on desktop. Researcher used prototyping methods to develop systems. In research generated by information system clinic of GKI Raya Hankam based on desktop can help patient data storage, drug data, record transactions and print receipt or payment transactions. This system can also help search patient data and drugs if the user wants to find the required data. The existence of this clinical information system, clinic of GKI Raya Hankam can easily meet the needs and manage patient data, medicine and payment.
\end{abstract}

Keywords: clinic, deskto, prototyping, system

\begin{abstract}
Abstrak: Klinik GKI Raya Hankam merupakan fasilitas layanan kesehatan yang dimiliki oleh Gereja Kristen Indonesia. Klinik GKI Raya Hankam bertujuan untuk melayani kesehatan untuk masyarakat umum yang memiliki masalah dengan kesehatan. Tujuan dilakukannya penelitian ini adalah untuk membangun dan mengimplementasikan suatu sistem informasi klinik GKI Raya Hankam berbasis desktop. Peneliti menggunakan metode prototyping untuk mengembangkan sistem. Pada penelitian yang dihasilkan oleh Sistem Informasi Klinik GKI Raya Hankam Berbasis Desktop dapat membantu penyimpanan data pasien, data obat, mencatat transaksi, dan mencetak struk pembayaran atau transaksi. Sistem ini juga dapat membantu pencarian data pasien dan obat jika user ingin mencari data yang dibutuhkan. Adanya sistem informasi klinik ini, pengelola klinik GKI Raya Hankam dapat dengan mudah memenuhi kebutuhan dan mengelola data pasien, obat dan pembayaran.
\end{abstract}

Kata Kunci: desktop, klinik, prototyping, sistem

\section{PENDAHULUAN}

Perkembangan zaman ilmu pengetahuan dan teknologi berkembang pesat. Terutama ilmu pengetahuan dan teknologi dalam bidang kesehatan. Kesehatan merupakan faktor yang paling penting buat masyarakat, untuk itu diperlukan suatu tempat untuk menangani pelayanan di bidang kesehatan. Komputer juga alat bantu kerja dalam bidang kesehatan.

Penggunaan teknologi komputer dapat memberikan kemudahan dan mempercepat pekerjaan sehingga menjadi efektif dan efisien apabila dapat memenuhi kriteria yang dihasilkan, seperti keakuratan informasi yang dihasilkan, ketepatan waktu di dalam pemberian informasi serta pemanfaatan informasi yang diberikan kepadai pemakainya[1]. Salah satu dari teknologi komputer yaitu aplikasi desktop.
Aplikasi desktop merupakan aplikasi yang mampu beroperasi secara offline, tetapi harus diinstal terlebih dahulu pada pengguna.

Kesehatan merupakan hal yang paling penting yang harus dijaga dalam tubuh. Maka usaha bidang kesehatan didirikan sesuai kebutuhan di gereja. Bidang kesehatan banyak tempatnya seperti rumah sakit, klinik, puskesmas. Olahraga pun juga termasuk dalam menjaga kesehatan tubuh. Makanan merupakan asupan agar tubuh tetap terjaga. Jika kesehatan dalam tubuh tidak sehat, maka harus diperiksa ke tempat yang dapat memberikan pengobatan.

Klinik GKI Raya Hankam merupakan fasilitas layanan kesehatan yang dimiliki oleh Gereja Kristen Indonesia. Klinik GKI Raya Hankam bertujuan untuk melayani kesehatan untuk masyarakat umum yang memiliki masalah dengan kesehatan. Proses yang 
dilakukan pada klinik GKI Raya Hankam, pasien datang ke klinik GKI Raya Hankam dan mendaftarkan pasien ke administrasi. Setelah mendaftarkan pasien, perawat klinik akan mencatat nama pasien di buku pendaftaran dan pasien menunggu di ruang tunggu. Lalu pasien akan dipanggil sesuai urutan nomor yang telah dicatat pada buku pendaftaran dan konsultasi terlebih dahulu oleh dokter untuk mengetahui masalah kesehatan yang dimiliki oleh pasien. Setelah konsultasi, pasien akan diperiksa oleh dokter klinik di ruang pemeriksaan. Dokter akan menyarankan obat kepada pasien untuk memulihkan pada kesehatan pasien. Lalu pasien menanyakan harga obat ke administrasi. Administrasi akan memberikan obat yang disarankan oleh dokter kepada pasien dan menjelaskan pemakaian obat tersebut dan harganya. Pasien akan membeli obat di administrasi dan perawat akan mencatat bukti pembelian obat di buku kwitansi dan microsoft excel. Perawat memberikan obat dan kwitansi kepada pasien beserta pemakaian obatnya.

Saat ini sistem yang dimiliki oleh klinik GKI RayaHankam masih manual sepertiproses pendaftaran pasien masih menggunakan buku pendaftaran, bukti pembayaran hanya mengunakan kwitansi, sedangkan untuk mencatat data transaksi masih menggunakan microsoft excel sehingga masih terjadi kesalahan data yang tidak tercatat dan redudansi data. Selain itu klinik GKI Raya Hankam tidak memiliki data dan riwayat penyakit pasien dan juga tidak memiliki rekapitulasi pencatatan obat-obatan dan peralatan. Oleh karena itu, pasien menunggu lama dalam antriannya untuk diperiksa oleh dokter dan pembelian obat.

Berdasarkan uraian permasalahan yang di hadapi saat ini maka dapat di ambil suatu perumusan masalah yaitu: 1) Bagaimana membangun sistem informasi klinik GKI Raya Hankam berbasis desktop?; 2) Bagaimana memudahkan tugas pengelola atau perawat klinik GKI Raya Hankam untuk memasukkan data pasien, menampilkan nama obat dan harga obat?; 3) Bagaimana memudahkan proses transaksi untuk pembelian obat di klinik GKI Raya Hankam?. Tujuan penelitian ini adalah untuk membangun dan mengimplementasikan suatu sistem informasi klinik GKI Raya Hankam berbasis desktop. Sistem Informasi tidak akan lepas dari teknologi informasi artinya keberhasilan atau kesuksesannya akan selalu didukung oleh adanya teknologi informasi. SI merupakan gabungan antara hardware dan software komputer, prosedur-prosedur, dokumentansi, formulir-formulir dan orang yang bertanggung jawab untuk mengumpulkan, mengolah, dan mendistribusikan data dan informasi.[2]

\section{METODE PENELITIAN}

Berikut ini merupakan metode penelitian yang dilakukan oleh peneliti dalam membangun sistem informasi klinik. Tahapan penelitian atau alur berpikir yang dilakukan oleh peneliti yaitu dimulai dari studi pendahuluan, kemudian mengumpulkan data seperti data pasien dan data obat dengan melakukan observasi dan wawancara. Setelah itu menganalisis sistem yang berjalan pada saat ini di klinik GKI Raya Hankam. Setelah mengetahui sistem berjalan yang saat ini dilakukan oleh klinik GKI Raya Hankam, peneliti mengidentifikasi masalah yang terjadi. Lalu peneliti mengusulkan sistem kepada klinik untuk mengurangi masalah. Peneliti mengidentifikasi kebutuhan yang akan dibutuhkan oleh klinik terhadap sistem. Setelah mengidentifikasi kebutuhan, maka peneliti membangun sebuah prototype dengan merancang mock up serta fitur-fitur yang dibutuhkan oleh klinik.

Berdasarkan Gambar 1. Dapat dijelaskan sebagai berikut: 1) Studi Pendahuluan: Peneliti melakukan pengamatan secara langsung terhadap klinik dan mencari sebuah permasalahan yang ada dalam klinik dalam membangun sistem; 2) Pengumpulan data: Peneliti melakukan observasi dan wawancara kepada penanggungjawab klinik untuk mendapatkan data dan informasi dari klinik yang diteliti, sehingga dapat memberikan suatu gambaran dari masalah yang sudah pernah ada sebelumnya; 3) Analisis Sistem Berjalan: Peneliti menganalisis sistem yang berjalan pada saat ini di klinik GKI Raya Hankam seperti pendaftaran pasien, memasukkan data obat dan pencatatan transaksi; 4) Identifikasi Masalah: Peneliti melakukan identifikasi masalah yang terjadi di klinik; 5) Analisis Sistem Usulan: Penggunaan bahasa pemrograman Java dipilih oleh peneliti dikarenakan bahasa pada saat ini paling fleksibel, bisa berada hampir di semua platform dan bisa dikembangkan nantinya oleh pengembang lain bila ingin menambahkan fitur-fitur lainnya. Penggunaan database MySQL dipilih karena tidak dipungut biaya apapun, bisa digunakan diberbagai platform, fleksibel dengan bahasa pemrograman seperti Java, PHP, C++, dan yang lainnya.

\section{A. Prototype}

Peneliti mengusulkan sistem pada klinik dengan alur prototype yang digunakan sebagai metode dalam melakukan pengembangan sistem.[3]: (1) Identifikasi Kebutuhan: Merencanakan dan mengumpulkan data mengenai apa saja yang dibutuhkan oleh sistem; (2) Mengembangkan Prototype: Melakukan analisa 


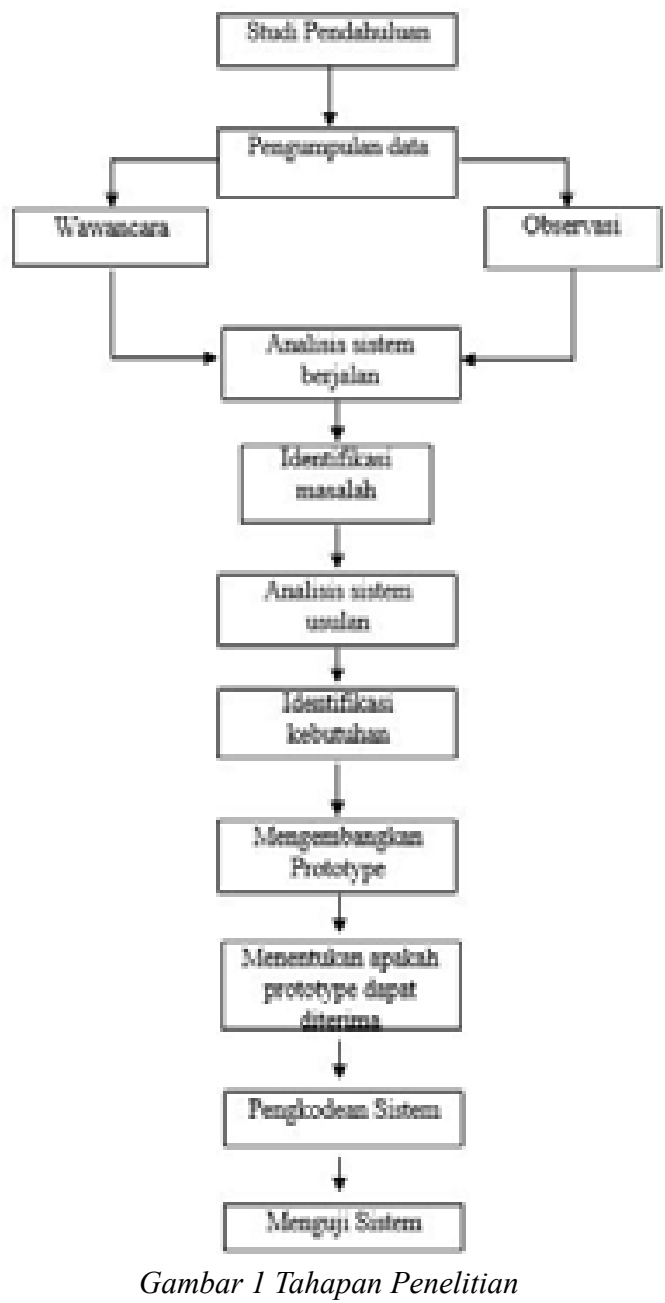

masalah pada sistem tersebut, sehingga diperoleh sebuah solusi dari masalah yang ada beserta pembuatan sistemnya; (3) Menentukan apakah Prototype dapat diterima: Melakukan analisa kepada pengguna yang akan menggunakan sistem tersebut. Jika disetujui, maka sistem akan dilanjutkan ke tahapan selanjutnya, dan bila tidak setuju maka akan dilakukan revisi terhadap prototype; (4) Pengkodean Sistem: Melakukan tahap pengkodean (Coding); (5) Menguji Sistem: Peneliti melakukan tes pada sistem yang sudah dibuat; (6) Menentukan Jika Sistem Operasional Dapat Diterima: Peneliti memberikan sistem yang sudah jadi kepada pemakai untuk mendapatkan masukan (apakah sistem dapat diterima/ tidak); (7) Menggunakan Sistem Operasional: Mengimplementasikan sistem prototype yang telah dibuat.

Metode ini dipilih, karena peneliti saling berinteraksi dengan end-user selama tahap pengerjaan, menghemat waktu dikarenakan meminimalisir akan adanya kesalahan dikarenakan pengguna ikut memberitahukan apa yang diinginkan sehingga peneliti dapat menyesuaikan dengan kebutuhannya.

Dibandingkan dengan Metode Waterfall yang tahapannya kurang fleksibel dan tidak dapat diubah- ubah serta harus jelas dan sesuai prosedur. Model ini melakukan pendekatan secara sistematis dan urut mulai dari level kebutuhan sistem lalu menuju ke tahap analisis, desain, coding, testing / verification, dan maintenance. Disebut dengan waterfall karena tahap demi tahap yang dilalui harus menunggu selesainya tahap sebelumnya dan berjalan berurutan. Sebagai contoh tahap desain harus menunggu selesainya tahap sebelumnya yaitu tahap requirement. [4]

Pembuatan basis data pun juga dibuat oleh peneliti yang di dalam basis data tersebut terdapat beberapa tabel, dan sudah dalam proses pengkodingan.

\section{B. Unified Modeling Language}

Unified Modeling Language atau UML didefinisikan sebagai tujuan umum pemodelan standar di bidang rekayasa perangkat lunak berorientasi objek. Perangkat ini mencakup teknik notasi grafis untuk membuat model visual system intensif dengan perangkat lunak berorientasi objek.

UML adalah alat untuk menentukan dan memvisualisasikan system perangkat lunak. UML termasuk jenis diagram standar yang menggambarkan dan visual memetakan aplikasi computer atau desain system database dan struktur. Penggunaan UML sebagai alat untuk menentukan struktur system adalah cara yang sangat berguna untuk mengelola besar system yang kompleks. UML memiliki struktur yang terlihat jelas dan memudahkan untuk memperkenalkan orang baru untuk proyek yang sudah ada. UML yang digunakan untuk menentukan, me-visualisasikan, memodifikasi, membangun dan dokumen artefak dari sistem perangkat lunak-intensif berorientasi objek dalam pengembangan. UML juga menawarkan cara standar untuk memvisualisasikan sistem blueprint arsitektur, termasuk unsur seperti: kegiatan, aktor, proses bisnis, skema database, komponen, laporan bahasa pemrograman serta komponen software yang dapat digunakan kembali. [5]

\section{HASIL DAN PEMBAHASAN}

\section{A. Analisis Sistem Berjalan}

Proses sistem berjalan di klinik GKI Raya Hankam sampai saat ini yaitu pasien datang ke loket pendaftaran, jika pasien baru akan dibuatkan kartu klinik dan akan dibawa terus oleh pasien yang ingin berobat ke klinik dan ditunjukkan di bagian pendaftaran supaya bisa dicari status pasien pada buku index. Jika pasien lama, pasien hanya menunjukkan kartu klinik ke bagian pendaftaran dan akan dicari nama pasien yang terdaftar pada 
buku index. Jika satu keluarga hanya mempunyai satu kartu klinik, maka kartu tersebut bisa digunakan untuk satu keluarga. Setelah mendaftar, pasien akan diberikan nomor antrian, kemudian pasien menunggu di ruang tunggu sampai kartu tersebut selesai dicari sesuai yang terdaftar di buku index.

Setelah administrasi menemukan nama pasien pada buku index, maka pasien akan mendapatkan nomor urut untuk dipanggil. Setelah dipanggil dan telah diperiksa oleh dokter, dokter akan bertanya apakah pasien membutuhkan obat atau tidak. Jika tidak membutuhkan obat, maka dokter akan memberikan saran untuk dan pasien hanya membayar uang registrasi sebesar Rp. 10.000,00 ke kasir. Jika pasien membutuhkan obat, maka dokter akan memberikan resep obat kepada pasien dan pasien akan menyerahkan resep tersebut ke kasir. Bagian kasir akan menerima resep obat dari pasien dan kasir akan menyerahkan resep obat kepada bagian farmasi untuk diracik. Pasien akan menunggu sampai dipanggil oleh bagian kasir. Setelah pasien dipanggil oleh bagian kasir, pasien membayar obat dan pendaftaran. Kasir akan mencatat transaksi di buku dan dibuatkan kwitansi untuk pasien. Pasien menerima obat dan kwitansi sebagai bukti transaksi, seperti pada Gambar 3 .

\section{B. Analisis Sistem Usulan}

Sistem usulan yang diusulkan oleh peneliti berisikan kebutuhan data, rancangan sistem, perancangan UML, dan rancangan antarmuka.

Kebutuhan Data Fungsional dan Non Fungsional. Kebutuhan data fungsional adalah kebutuhan yang dibutuhkan oleh sistem. Kebutuhan fungsional berisi tentang hal-hal yang dilakukan dan dihasilkan oleh sistem. Kebutuhan data non fungsional adalah kebutuhan yang tidak secara langsung terkait dengan fitur-fitur yang ada dalam sebuah sistem.

Adapun perangkat lunak yang dibutuhkan dalam membangun sistem ini adalah sebagai berikut: Sistem Operasi Windows 10 Home; XAMPP 3.2.2 (Database MySQL server). Database adalah sebuah sistem yang berfungsi untuk menyimpan dan mengolah sekumpulan data. Setiap database mempunyai API tertentu untuk membuat, mengakses, mengatur, mencari, dan menyalin data yang ada di dalamnya sehingga bisa dimanfaatkan oleh aplikasi lainnya.[6]

MySQL merupakan software RDBMS (atau server database) yang dapat mengelola database dengan sangat cepat, dapat menampung jumlah sangat besar, dapat diakses oleh banyak user (multi-user), dan dapat melakukan suatu proses secara sinkron atau

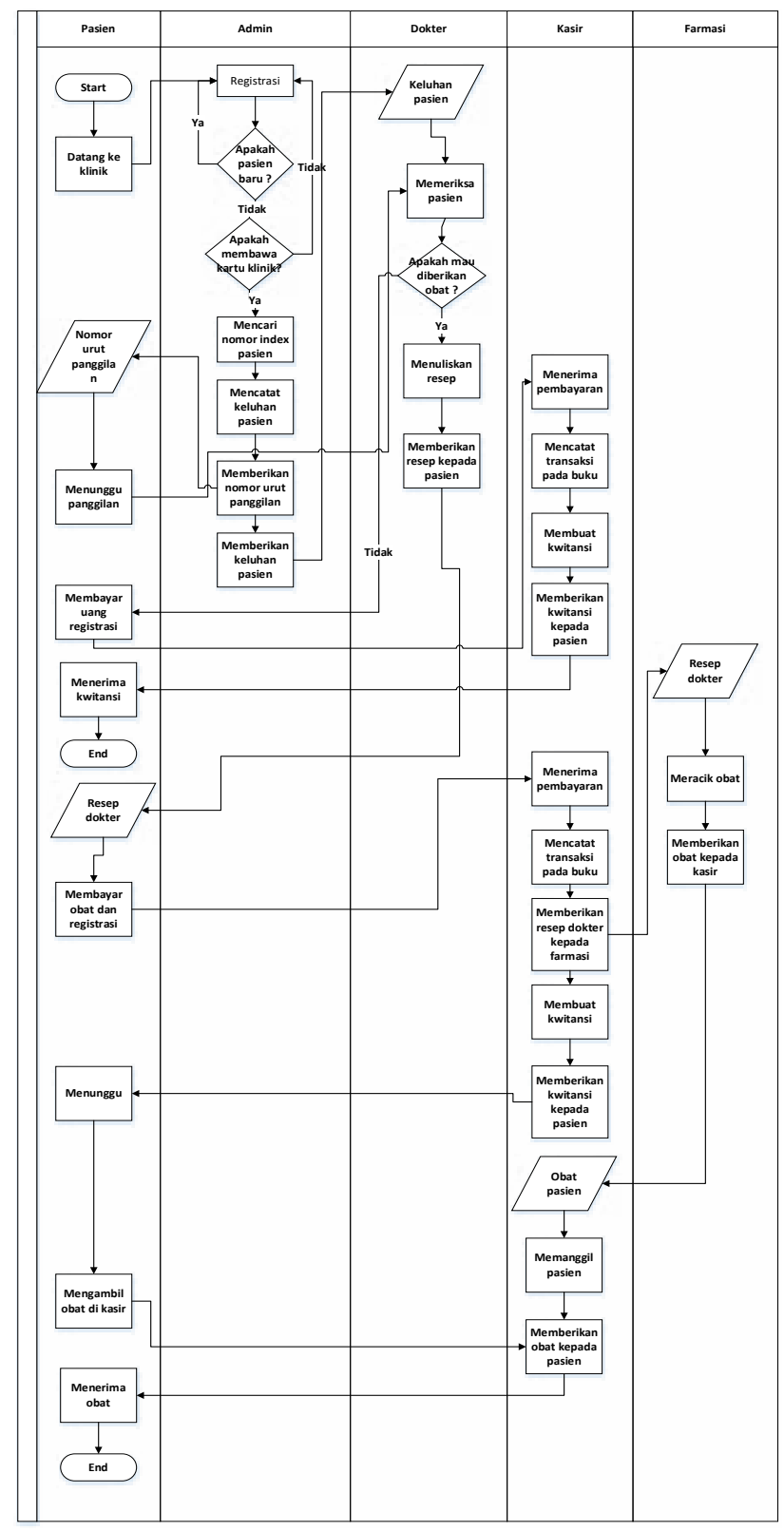

Gambar 3 Flowchart klinik sistem berjalan

berbarengan (multi-threaded).[8]

Program Editor (Netbeans IDE 8.2). Netbeans merupakan IDE (Integrated Development Environment) untuk membuat aplikasi dengan Java, PHP, C, C++, dan HTML5.Netbeans IDE bekerja menyerupai Microsoft Visual Studio atau Dreamweaver dalam konteks sebagai aplikasi yang memiliki lingkungan kerja lengkap untuk membangun aplikasi lain[7].

Bahasa Pemrograman Java. Merupakan bahasa pemrograman yang sangat popular dikarenakan rentang aplikasi yang bisa dibuat menggunakan bahasa ini sangatlah luas, mulai dari komputer hingga smartphone. Bahasa ini diakuisisi oleh Oracle Corporation. Beberapa kelebihan pada bahasa ini seperti berorientasi objek, sederhana, aman, portable, dan yang lainnya. J2SE atau Java2 Standard Edition adalah inti dari bahasa pemrograman Java. JDK 
(Java Development Kit) adalah salah satu tool dari J2SE untuk mengompilasi dan menjalankan program Java yang dapat membuat aplikasi desktop.[7]; Visio 2013; dan Star UML

\section{Rancangan Sistem}

Perancangan sistem memiliki tujuan untuk memenuhi kebutuhan pemakai mengenai gambaran tentang aplikasi yang akan dibuat oleh peneliti setelah melalui tahapan analisa sistem. Analisa ini digunakan untuk mengembangkan dari sistem yang lama menjadi sistem yang baru. Dari hasil analisis yang dilakukan, didapatkan Use-Case, Class dan Activity Diagram.

Berikut adalah diagram-diagram UML beserta penjelasannya: Usecase Diagram. Use-case bersifat statis. Diagram ini memperlihatkan himpunan use-case dan aktor-aktor (suatu jenis khusus dari kelas). Diagram ini terutama sangat penting untuk mengorganisasikan dan memodelkan perilaku suatu sistem yang dibutuhkan serta diharapkan pengguna[9]; Use-case diagram adalah fungsi yang disediakan oleh aplikasi komputer yang dapat diilustrasikan dengan diagram use case. Tujuan utamanya adalah untuk memvisualisasikan kebutuhan fungsional dari sistem termasuk hubungan "aktor"(orang yang akan berinteraksi dengan sistem) untuk proses penting, serta hubungan kasus penggunaan yang berbeda. Ini adalah daftar langkah-langkah yang biasanya mendefinisikan interaksi antara peran (dikenal dalam UML sebagai "aktor") dan system untuk mencapai suatu tujuan.

Use case diagram menggambarkan kegiatan yang terdapat dalam sistem. Apa saja yang terjadi dalam sistem dan siapa saja yang melakukan kegiatan tersebut. Use Case diagram juga dapat memberikan gambaran sejauh mana fungsi dan kemampuan sistem yang akan dibangun.

Use-Case diagram pada sistem klinik GKI Raya Hankam yang akan dibangun oleh peneliti yang dapat dilihat pada Gambar 4. Class Diagram adalah struktur aplikasi komputer atau stasiun basis data yang ditampilkan dalam diagram kelas. Hal ini juga menunjukkan bagaimana entitas yang berbeda dan berhubungan satu sama lain. Hal ini dapat digunakan untuk menampilkan kelas logis, dan kelas implementasi. Ini merupakan blok bangunan utama berorientasi objek modeling. Class diagram juga merupakan jenis diagram berstruktur statis dalam UML yang menggambarkan struktur dari suatu system dengan menunjukkan kelas system, atribut, operasi, dan hubungan di antara kelas-kelas.

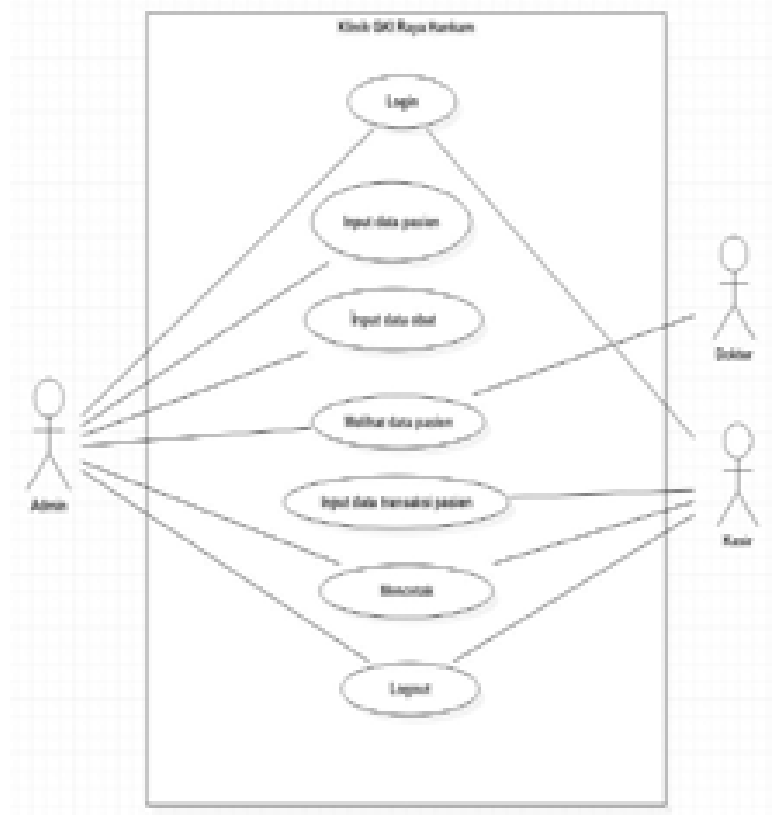

Gambar 4 Usecase diagram

Class diagram juga menunjukkan atribut-atribut dan operasi-operasi dari sebuah kelas dan constraint yang berhubungan dengan objek yang dikoneksikan. Class diagram secara khas meliputi: Kelas (Class), Relasi, Atribut, Operasi, Visibility, tingkat akses objek eksternal kepada suatu operasi atau atribut. Class diagram adalah struktur aplikasi komputer yang ditampilkan dalam diagram kelas. Class diagram juga menunjukkan atribut-atribut dan operasi-operasi dari sebuah kelas yang berhubungan dengan objek yang dikoneksikan. seperti pada Gambar 5.

Activity diagram adalah kontrol prosedural antara dua atau lebih objek kelas saat memproses suatu kegiatan dapat ditampilkan dengan diagram aktivitas. Hal ini dapat digunakan untuk model proses bisnis tingkat tinggi pada tingkat unit bisnis atau untuk model tindakan kelas internal pada tingkat rendah. Activity Diagram menggambarkan workflow atau aktivitas dari sebuah sistem atau proses bisnis.

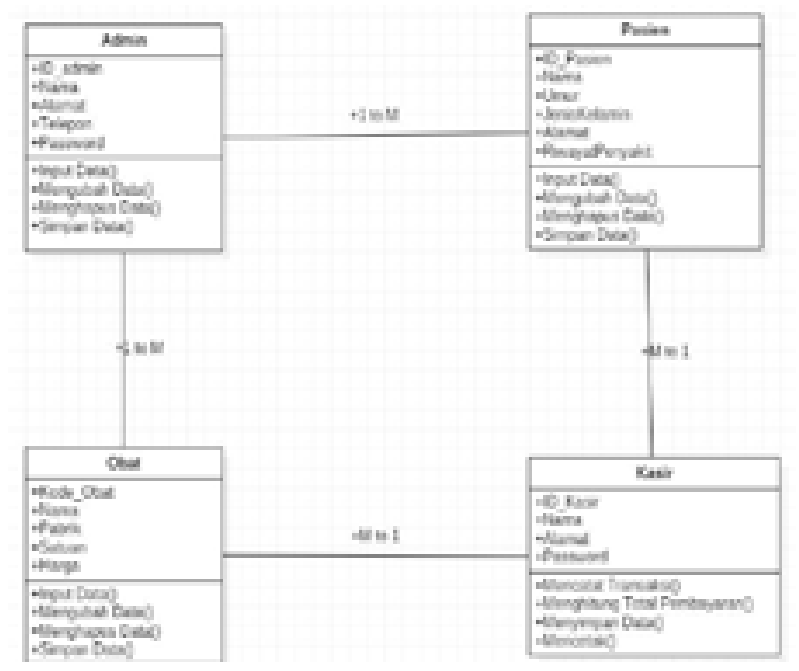

Gambar 5 Class diagram 
Berikut ini adalah gambaran activity diagram admin pada sistem klinik GKI Raya Hankam yang akan dibangun oleh peneliti. seperti pada Gambar 6, Gambar 7 dan Gambar 8.

\section{Rancangan Antarmuka}

Rancangan antarmuka yang dibangun oleh peneliti dirancang agar mudah dipahami oleh admin

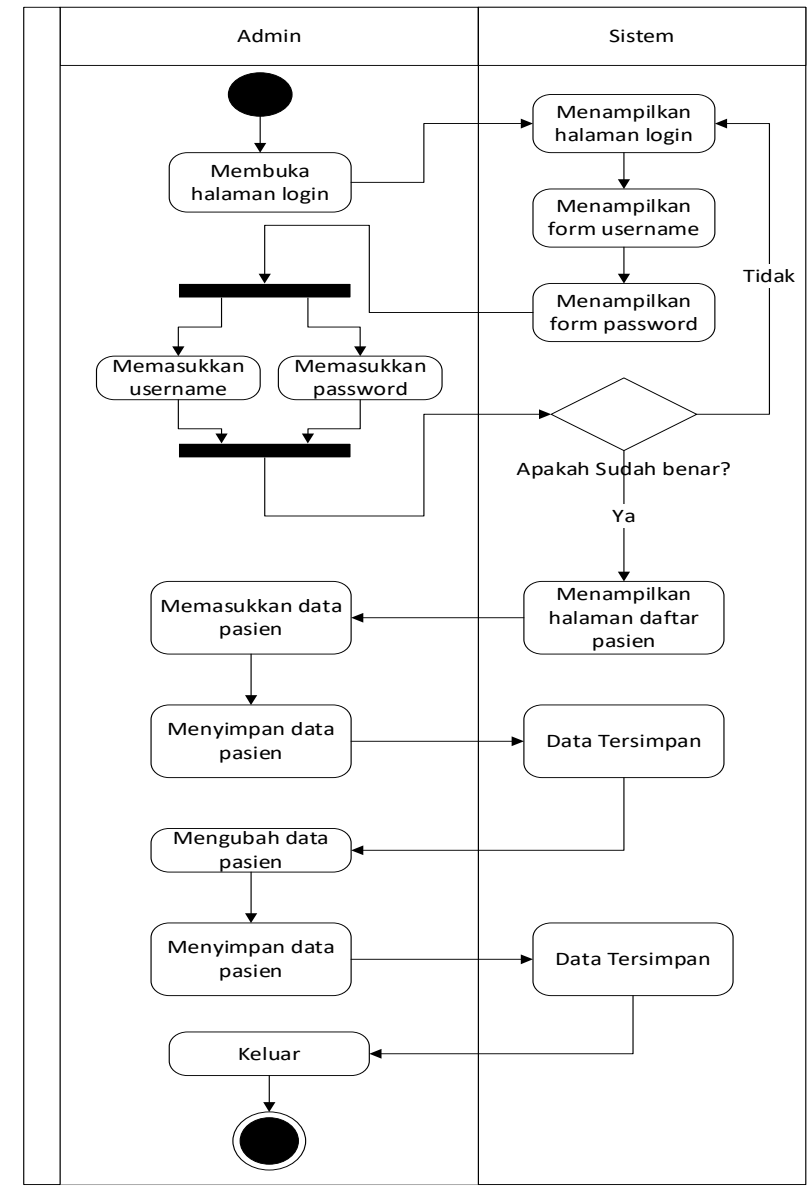

Gambar 6 Activity diagram admin dengan data pasien

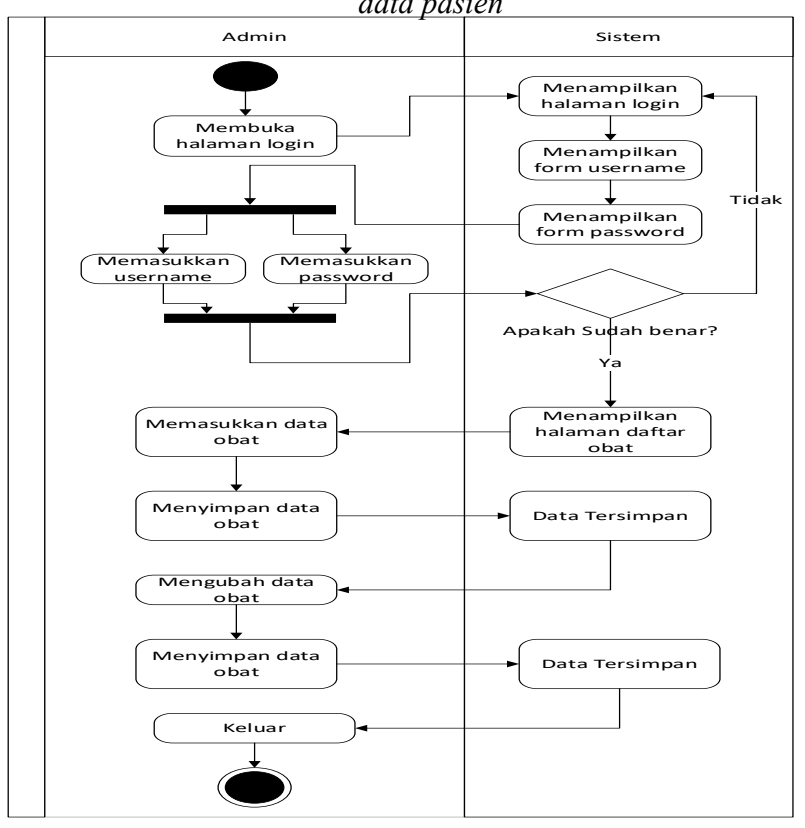

Gambar 7 Activity diagram admin dengan daftar obat

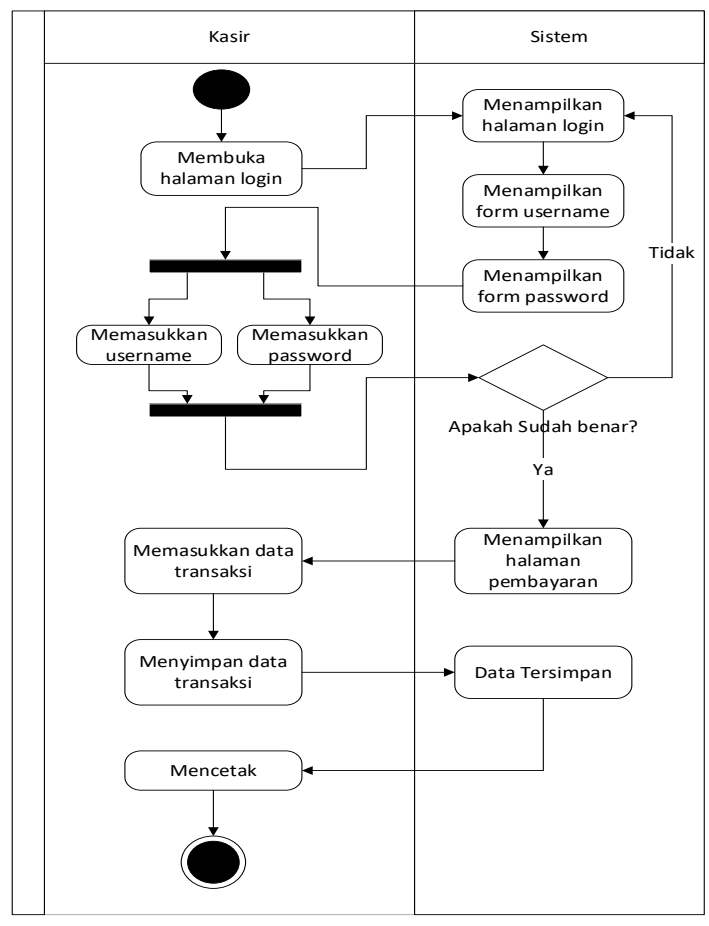

Gambar 8 Activity diagram pada kasir

maupun kasir. Halaman yang dibuat oleh peneliti untuk bagian admin yaitu login, halaman utama, profil, daftar obat, daftar pasien, dan logout. Halaman yang dibuat oleh peneliti untuk bagian kasir yaitu login dan halaman pembayaran.

\section{Rancangan Halaman Login}

Pada halaman login, admin dan kasir akan memasukan username dan password.Jika berhasil, maka admin dapat membuka halaman selanjutnya yaitu halaman menu utama pada hak akses masingmasing. Dapat dilihat pada Gambar 9.

\section{Klinik GKI Raya Hankam}

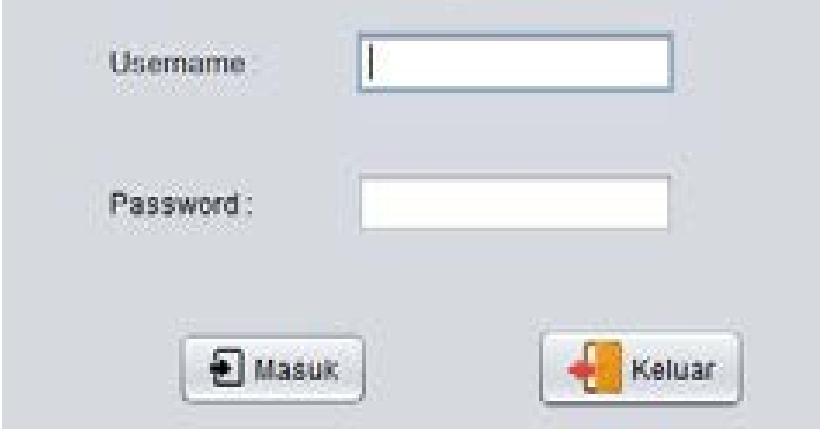

Gambar 9 Tampilan halaman login

\section{Rancangan Menu Utama Pada Admin}

Pada halaman menu admin, admin dapat memilih menu profil, daftar obat, daftar pasien, dan keluar jika admin ingin keluar dari menu admin. Dapat dilihat Admin pada Gambar 10. 


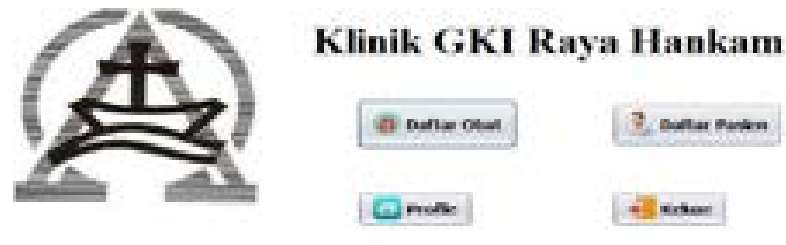

Gambar 10 Menu utama pada admin

\section{Rancangan Halaman Profil}

Pada halaman ini, admin dapat melihat visi dan misi klinik GKI Raya Hankam.. Dapat dilihat pada Gambar 11.

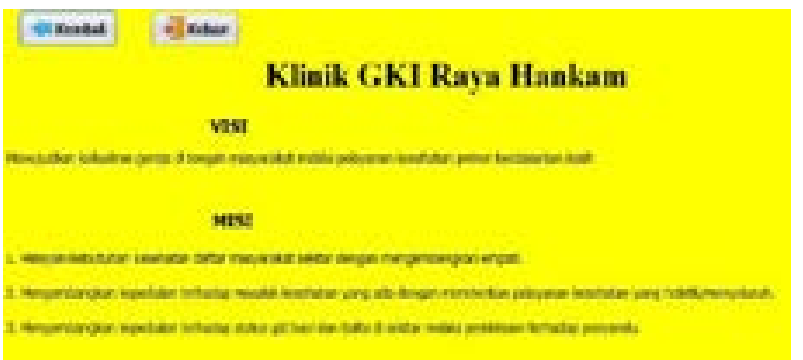

Gambar 11 Halaman profil

\section{Rancangan Halaman Obat}

Pada halaman ini, admin dapat memasukkan kode obat, nama obat, dan harga obat yang tersedia di klinik. Setelah dimasukkan, maka data obat akan disimpan ke dalam database dengan cara menekan tombol simpan. Admin dapat mengubah data dengan cara menekan tombol ubah yang sudah tersedia jika ada perubahan pada data. Admin juga dapat menghapus data dengan menekan tombol hapus atau menekan tombol bersihkan jika terjadi kesalahan dalam memasukkan data. Tombol cari digunakan untuk mencari data yang diinginkan oleh admin

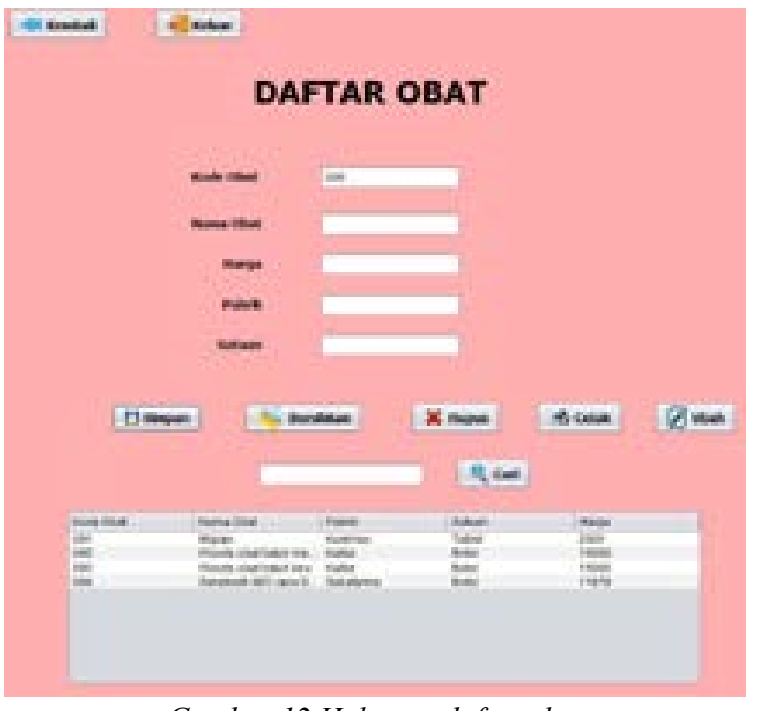

Gambar 12 Halaman daftar obat dengan cara memasukkan kode obat atau nama obat. Tombol cetak digunakan untuk mencetak data obat yang berada dalam table obat. Dapat dilihat pada Gambar 12.

\section{Rancangan Halaman Daftar Pasien}

Pada halaman ini, admin dapat memasukkan data pasien yang terdiri dari ID pasien, nama pasien, umur, jenis kelamin, dan alamat. Admin dapat menyimpan data pasien setelah memasukkan data pasien dan menekan tombol simpan pada sistem. seperti pada gambar 13 .

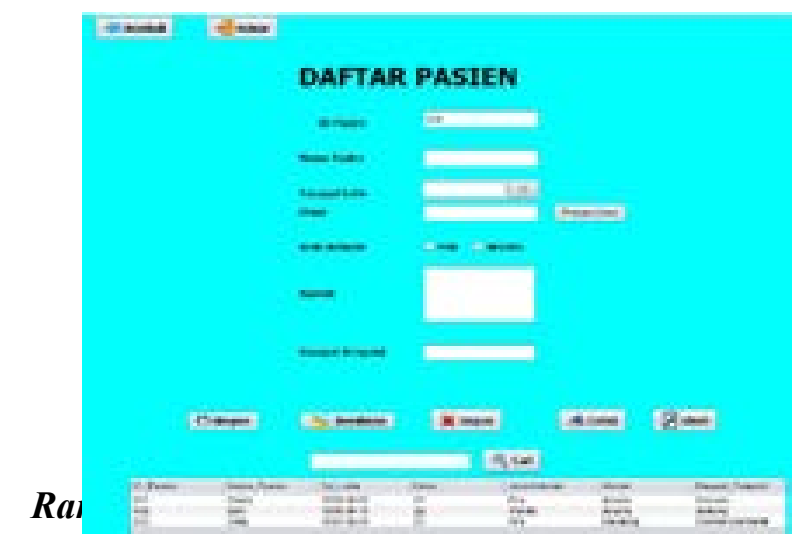

Pada halaman ini, kasir melakukan pencatatan transaksi. Halaman utama kasir pada sistem yaitu pembayaran. Kasir dapat memasukkan data yang terdiri dari kode obat, nama obat, nama pasien, nama dokter, harga obat, jumlah barang, biaya registrasi, total harga, tanggal transaksi, dan diagnosa. Kasir dapat menghitung total harga obat yang dibeli oleh pasien serta hitung kembalian. Dapat dilihat seperti pada Gambar 14.

\section{E. Pengujian Sistem}

Pengujian Alpha dilakukan hanya oleh pemilik

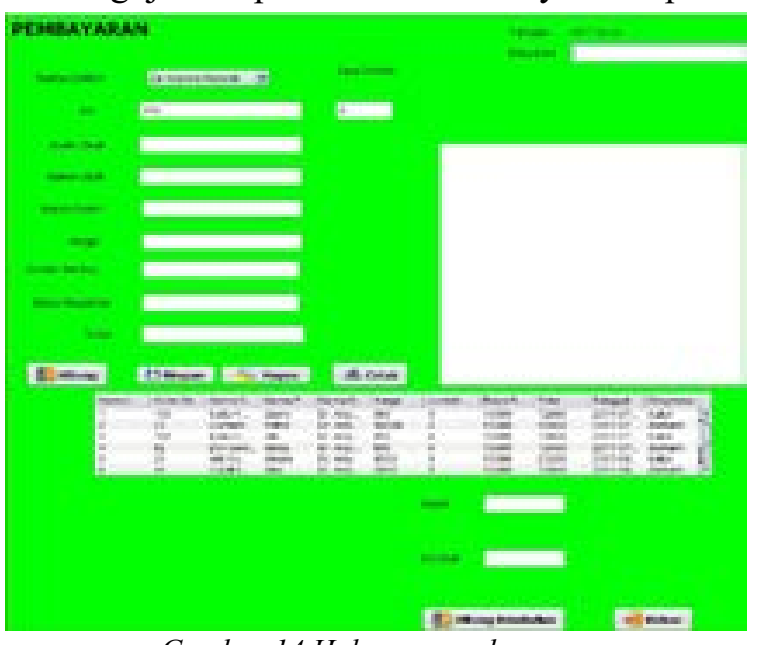

Gambar 14 Halaman pembayaran 
atau penanggungjawab klinik, supaya dalam pengujian suatu program/aplikasi dapat dilakukan lebih cepat. Sangat tidak mungkin bagi pengembang perangkat lunak untuk meramal bagaimana pelanggan akan benar-benar menggunakan program. Instruksi-instruksi yang digunakan mungkin bisa disalahartikan. Kombinasi data yang aneh dapat dipakai secara reguler. Output yang tampak jelas untuk penguji mungkin saja tidak dimengerti oleh pengguna di lapangan.

Ketika perangkat lunak dibangun untuk satu pelanggan, serangkaian pengujian penerimaan pun dilakukan agar pelanggan dapat memvalidasi semua persyaratan. Dilakukan oleh pengguna akhir daripada oleh rekayasawan perangkat lunak, pengujian penerimaan dapat berkisar "test drive" informal sampai serangkaian pengujian yang dilaksanakan secara terencana dan sistematis. Bahkan, pengujian penerimaan dapat dilakukan selama beberapa minggu atau bulan, sehingga dapat menemukan kesalahan kumulatif yang dapat menurunkan sistem dari waktu ke waktu. Pengujian alpha dilakukan di sisi pengembang oleh sekelompok perwakilan dari pengguna akhir. Perangkat lunak ini digunakan dalam kondisi natural dimana pengembang "melihat dengan kacamata" pengguna dan mencatat kesalahankesalahan dan masalah-masalah penggunaan alpha dilakukan dalam lingkungan yang dikendalikan [10].

Metode yang digunakan oleh peneliti dalam penelitian di klinik GKI Raya Hankam adalah metode black box testing. Pengujian black-box berfokus pada persyaratan fungsional perangkat lunak. Dengan demikian, pengujian black box memungkinkan perekayasa perangkat lunak mendapatkan serangkaian kondisi masukan yang menggunakan semua persyaratan fungsional untuk suatu program.

Pengujian kotak hitam juga disebut pengujian perilaku, berfokus pada persyaratan fungsional perangkat lunak. Artinya, teknik pengujian kotak hitam memungkinkan Anda untuk membuat beberapa beberapa kondisi masukan yang sepenuhnya akan melakukan semua kebutuhan fungsional untuk program. Pengujian kotak hitam bukan teknik alternatif untuk kotak putih. Sebaliknya, ini merupakan pendekatan pelengkap yang mungkin dilakukan untuk mengungkap kelas kesalahan yang berbeda dari yang diungkap oleh metode kotak putih.

Dengan menerapkan teknik kotak hitam, Anda mendapatkan serangkaian test case yang memenuhi kriteria berikut: (1) test case yang mengurangi dengan jumlah yang lebih besar dari satu sampai jumlah test case tambahan yang harus dirancang untuk pengujian yang wajar dan (2) test case yang mengatakan sesuatu tentang ada atau tidak adanya kelas kesalahan daripada kesalahan yang terkait dengan pengujian khusus yang telah dibuat. [11].

Berikut ini merupakan salah satu hasil dari testing pada halaman login yang dilakukan oleh peneliti dimana pada tabel tersebut menunjukkan kesesuaian prosedur keamanan login yaitu ketika password atau username salah maka akan muncul pesan gagal. Bila berhasil ada pesan berhasil melakukan login. Keduanya dilakukan dengan proses verifikasi identitas.

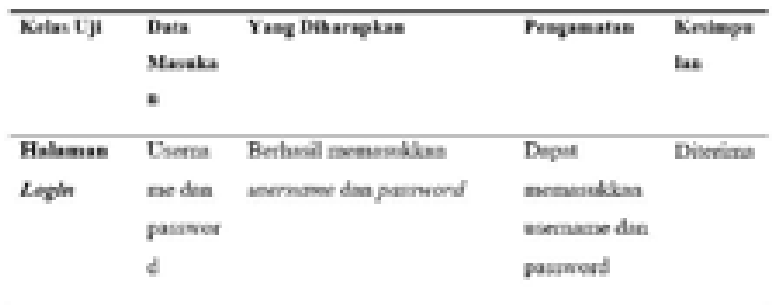

Gambar 15 Testing halaman login

\section{SIMPULAN}

Pada penelitian yang dihasilkan oleh Sistem Informasi Klinik GKI Raya Hankam Berbasis Desktop dapat membantu penyimpanan data pasien, data obat, mencatat transaksi, dan mencetak struk pembayaran atau transaksi. Sistem ini juga dapat membantu pencarian data pasien dan obat jika user ingin mencari data yang dibutuhkan. Adanya sistem informasi klinik ini, pengelola klinik GKI Raya Hankam dapat dengan mudah memenuhi kebutuhan dan mengelola data pasien, obat dan pembayaran.

\section{DAFTAR RUJUKAN}

[1] V. Tundjungsari. "Aplikasi Klinik Kesehatan Online Berbasis Web”. Jakarta: Fakultas Teknologi Informasi Universitas YARSI. 2008.

[2] R. Handayani.“Analisis Faktor-faktor Yang Mempengaruhi Minat Pemanfaatan Sistem Informasi dan Penggunaan Sistem Informasi”. Tesis Pascasarjana Magister Sains Akuntansi Universitas Diponegoro Semarang. 2007.

[3] Jr. M. Raymond, Sistem Informasi Manajemen Jilid I, Jakarta: Pearson Education Asia Pte. Ltd. dan PT Prenhallindo, 2001.

[4] R. A. Pascapraharastyan, dkk. "Rancang Bangun Sistem Informasi Manajemen Arsip Rumah Sakit Bedah Surabaya Berbasis Web". JSIKA Vol. 3. No. 1, ISSN 2338-137X, hlm. 140. 2014.

[5] L.Sunguk. "Unified Modeling Language (UML) 
for Database Systems and Computer Applications". Research Institute of Industrial Science and Technology Pohang, Korea. 2012.

[6] Belajar Java, Database, dan Netbeans dari Nol. Jakarta: PT Elex Media Komputindo, 2016. hlm. 1-2,6,7-8.

[7] Belajar Java, Database, dan Netbeans dari Nol. Jakarta: PT Elex Media Komputindo, 2016. hlm. 1-2,6,7-8.

[8] B. Raharjo. Belajar Otodidak Membuat Database menggunakan MySQL. Bandung:Informatika, 2011. hlm. 21-22.

[9] D. Tegarden et al. Systems Analysis and Design with UML. John Wiley \& Sons, Inc. 2012. hlm. $156,166,249,210$.
[10] R.S.Pressman. Rekayasa Perangkat Lunak. Terjemahan oleh Adi Nugroho dkk. Yogyakarta : Penerbit ANDI, 2012. Hlm. 570.

[11] R.S.Pressman. Rekayasa Perangkat Lunak. Terjemahan oleh Adi Nugroho dkk. Yogyakarta : Penerbit ANDI, 2012. Hlm. 597-598.

[12] R. McLeod dan S. George, Sistem Informasi Manajemen edisi 10. Jakarta: Salemba Empat, 2008. hlm. 173. 